\title{
Article
}

\section{Internet's handprint}

\author{
Anders S.G. Andrae \\ Huawei Technologies Sweden AB, Kista, Sweden; anders.andrae@huawei.com \\ Received: 25 January 2021; Accepted: 17 March 2021; Published: 31 March 2021.
}

\begin{abstract}
In this decade there will an unprecedented growth of generated data, computations, instructions, and operations. This growth may not compromise clean air, clean water and a sustainable energy and material usage, but rather facilitate these prerequisites for flora and fauna. There are many indications (expected trends and estimates) showing that the Internet Sector will be able to provide solutions to other Sectors such as Buildings, Transportation and Industry which will help reduce the total global consumption of energy and materials. For instance, products are replaced by virtual services e.g. by using e-readers instead of paperbacks, and transportation is avoided by online shopping or Internet meetings. This is more resource and energy efficient than before and entire sectors, like transport, industry, and agriculture can be optimized. Internet may foster new sustainable lifestyles which can lower the affluence despite certain rebound effects. The underlying idea is that e.g. human-related global greenhouse gas (GHG) supply can be significantly halted if existing and developing ICT Solutions are used in other sectors (and in the Internet infrastructure itself) to cause a handprint. Such solutions include products-sold-as-services, smart Grid and smart metering. Compared to earlier approaches, the 2020 transformative effects on smart work, land use and smart circularity are included in the discussion, as well as consequential LCA modelling. Internet's handprint will be 4-7 times its footprint in 2030. The handprint is highly dependent e.g. on how large share of the buildings can adopt smart metering and the product to service rate. Internet will in itself use intelligent ICT solutions as well as neuromorphic, reversible and superconducting computing as well as nanophotonics to mitigate its own material and energy use. However, more importantly the intelligent ICT solutions should be used in the rest of the society to reach efficiency goals. Power saving is a highly efficient strategy for cost reduction in the Internet Sector itself and beyond.
\end{abstract}

Keywords: Agriculture; Ammonia; Buildings; Grid; Circularity; Communication; Consequential LCA; Consequential handprint; Computing; Data center; Data traffic; Deflation; Devices; Electricity use; Forest; Footprint; Forecast; Functionalities; Handprint; Hydrogen; Information; Internet; Iand use; Marginal variable change vectors; Operations; Transport; Travel; Waste.

\section{Introduction}

I $\mathrm{n}$ the present decade there will be an unprecedented growth of generated data, computations, instructions and operations. This growth may not compromise clean air, clean water and a sustainable energy and material usage, but rather facilitate these prerequisites for flora and fauna. Overall, global primary energy consumption rises due to the Internet [1] and Internet's own electrical energy consumption is also rising [2-4]. Plausibly the global primary energy and electricity consumption would rise even faster without the handprint of certain ICT solutions. The Internet Sector is one of few which might off-set its own electrical energy consumption and GHG supply, i.e., its handprint [5] is larger than its footprint. There are many indications (expected trends and estimates) showing that the Internet infrastructure will be able to provide solutions within main Sectors such as Buildings, Transportation and Industry - which will help reduce (halt the increase of) the total global consumption of energy and materials [6]. Information and communications technologies (ICTs) can potentially contribute to reduce resource consumption through increased productivity in many Sectors by enabling total optimization and dematerialization, occasionally using artificial intelligence (AI) [7]. Internet's deflationary characteristics suggest that it has a handprint. AI and machine learning (ML) are cornerstones of intelligent ICT Solutions which make them unique compared to incremental improvements. For instance, products are replaced by virtual services, e.g., by using e-readers instead of paperbacks [8], 
transportation is avoided by online shopping or online chatting. This is more resource and energy efficient than before and entire sectors, like transport, industry, and agriculture can be optimized. Internet may foster new sustainable lifestyles which can lower the affluence despite certain rebound effects. E.g. e-reader adopters are yet to fully abandon paper books for e-books suggesting a total net increase [8]. The underlying idea is that e.g. total anthropogenic global GHG supply (TAGGHGS) can be significantly halted if existing and developing ICT Solutions are used in other sectors (and Internet itself [9]) to their "full potential" in a smart manner. Such solutions include Products-sold-as-Services, Smart Grid and Smart Metering. The avoidance potential is highly dependent e.g. on how large share of the building GHG supply can be reduced by Smart Metering [10,11].

Internet will use smart ICT solutions to keep its own material and electrical energy use under control. The smart ICT solutions could also be used in the rest of the society to reach environmental goals. Still, the Internet Sector itself has a huge responsibility to try to reach high annual electrical energy efficiency gains of $\approx 20 \%$ in data centers and networks. This seems to have been the case in the last decade. New technologies such as neuromorphic, reversible and superconducting computing as well as nanophotonics may help in this decade $[12,13]$. Several attributional life cycle assessments have shown that Internet's share of TAGGHGS may have been stable 2015-2020 [13]. However, although recent literature is divided[14], the trends of rampant instructions/second and slowing improvements of switching energy are very clear [12,14]. Related cryptocurrency mining electrical energy demand is on the rise but not necessarily the related GHG supply [15]. Therefore power saving is a highly efficient strategy for GHG supply reduction in the Internet itself and beyond. In this work, the potential TAGGHGS avoidance of using ICT Solutions for energy saving, compared to low adoption of ICT Solutions, is explored. An algorithm for the estimation is established.

\subsection{Objectives}

The objective of this prediction study is to estimate the changes (GHG is proxy) to occur between 2019 and 2030 if traditional technologies are replaced with Information and Communication Technology (ICT) technologies. Internet's scope according to $[16,17]$ consists of the use stage of end-user consumer devices, network infrastructure and data centers as well as the production of hardware for all. The attributional LCA approach $[16,17]$ may not be able to capture the actual GHG avoidance derived from the use of ICT solutions, as many of them have the ability to decrease the energy and material losses. Consequently, less energy and materials need to be produced and purchased by a final customer in order to consume the same quantity of product. A consequential LCA (CLCA) with a planetary system boundary is attempted for ICT solutions handprint.

\subsection{Hypotheses}

The hypothesis is that Internet's GHG supply will increase according to the expected scenario as outlined by Andrae [16]. Moreover, Internet's GHG supply is off-set already in 2020 by ICT Solutions and the handprint will be 6 times the footprint by 2030 .

\section{Materials and methods}

The approach for estimating Internet's direct GHG supply is established while the handprint potential of ICT solutions for TAGGHGS is less clear. Here, for the sake of modelling, the World is divided into seven sectors - Industry, Buildings, Transport, Travel, Agriculture, Waste and Land use. Then several ICT Solutions ability to reduce TAGGHGS in each sector is estimated. The approach is very much simplistic as there are highly granular Input-Output models $[9,18]$ which describe the economic flows of different sectors in the society. Therefore, the coupling of IO and LCA can be applied to model indirect impacts of changes in product inputs and outputs in several economic sectors [19]. The coupling of IO and LCA can cover all economic sectors in a large geographical boundary. All assumptions made are available in the Supplementary Information.

\subsection{Description of method for estimating Internet GHG supply}

The approach for Internet direct GHG supply follows the one outlined in [16] expected scenario. Table 1 shows some global trends assumptions derived from $[13,16]$. Trends for TAGGHGS are followed closely [20]. 
Table 1. Global Electricity demand and average GHG intensity 2019 to 2030.

\begin{tabular}{c|c|c|c|c} 
Year & $\begin{array}{c}\text { Total global } \\
\text { electricity demand (TWh) }\end{array}$ & $\begin{array}{c}\text { Total global internet } \\
\text { electricity demand (TWh) }\end{array}$ & $\begin{array}{c}\text { TWh renewable electricity } \\
\text { including Hydro (TWh) }\end{array}$ & $\begin{array}{c}\text { GHG intensity } \\
\text { in Gt CO2e/TWh }\end{array}$ \\
\hline 2019 & 27050 & 1950 & 7042 & 0.000545 \\
\hline 2020 & 27188 & 1988 & 7265 & 0.000543 \\
\hline 2021 & 27826 & 1986 & 7494 & 0.000542 \\
\hline 2022 & 28467 & 1987 & 7731 & 0.000540 \\
\hline 2023 & 29117 & 1997 & 7975 & 0.000538 \\
\hline 2024 & 29775 & 2015 & 8227 & 0.000536 \\
\hline 2025 & 30446 & 2046 & 8487 & 0.000535 \\
\hline 2026 & 31179 & 2139 & 8755 & 0.000533 \\
\hline 2027 & 31968 & 2288 & 9032 & 0.000533 \\
\hline 2028 & 32813 & 2493 & 9318 & 0.000532 \\
\hline 2029 & 33751 & 2791 & 9612 & 0.000532 \\
\hline 2030 & 34718 & 3218 & 9916 & 0.000533
\end{tabular}

\subsection{Handprint - description of method for estimating GHG supply reductions and power savings by ICT Solutions}

The overall methodological approach for estimating electricity demand and GHG supply handprint by the Internet in other Sub-Sectors (Industry, Transportation, Buildings, Agriculture, Land use and Waste) is described below. Land use leads to increased GHG supply if new plants (e.g. trees) are not planted which can absorb $\mathrm{CO}_{2}$. Waste (management) is a relevant Sub-Sector of its own, e.g. landfill, recycling, incineration etc.

\subsubsection{Consequential handprint LCA}

The functional unit of the CLCA is: global demand of electricity and TAGGHGS. Figure 1 shows the principle of provided functions replacing more inefficient ways.

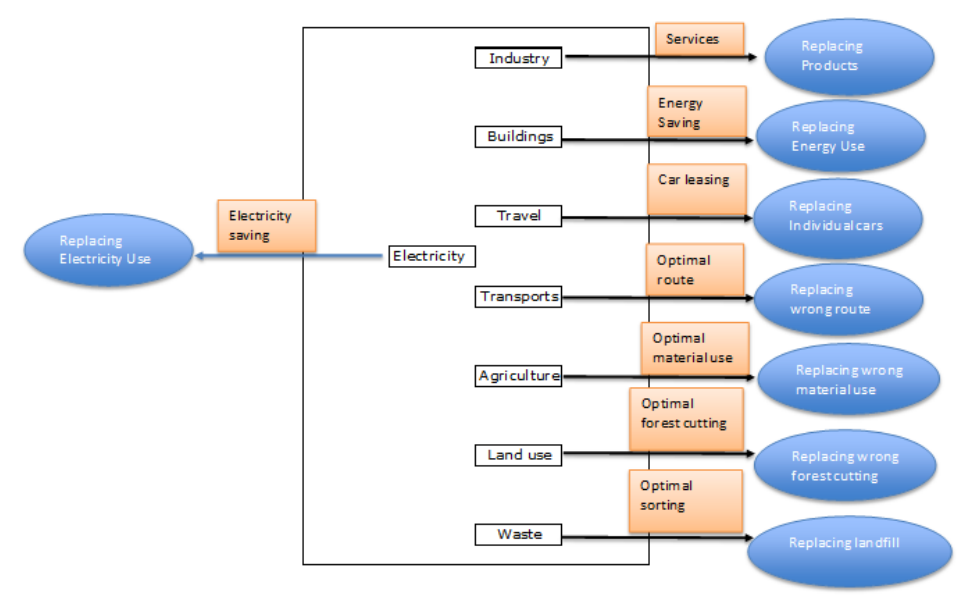

Figure 1. Consequential handprint principle of ICT Solutions.

ICT Solutions are replacing traditional solutions in the CLCA. Increased digitalization leads to increased production of ICT Solutions which substitute products, energy, materials and land use. When less travel and transport are used, also less fuel is produced. To compensate for "missing" fuel, more electricity will be produced. These effects contribute to the view of Internet driving deflation.

\subsection{Estimation of total anthropogenic global GHG supply}

The GHG supply from the Sub-Sector Agriculture in 2030 is $\approx 8.4 \mathrm{Gt}$ as shown in Table 2 below. Table 2 shows that Internet's share of TAGGHGS without Internet handprint will be low $(\approx 2 \%)$. Moreover, without active Internet handprint, Industry's GHG supply will increase almost 20\% between 2020 and 2030. Land use 
and waste environmental impacts are more challenging to reduce with ICT Solutions, but they still contribute to TAGGHGS which could rise between 2020 and 2030 [13].

Despite economic growth and rebound effects, TAGGHGS could likely be significantly halted if existing and future ICT Solutions are used in other sectors (and Internet itself). Table 2 shows the present estimations by Sector for approximate TAGGHGS.

Table 2. Estimation of total anthropogenic global GHG supply (Gigatonnes) by Sector 2019-2030

\begin{tabular}{|c|c|c|c|c|c|c|c|c|c|c|c|c|}
\hline $\begin{array}{l}\text { GHG Supply } \\
\text { from Global } \\
\text { Sectors and ICT }\end{array}$ & 2019 & 2020 & 2021 & 2022 & 2023 & 2024 & 2025 & 2026 & 2027 & 2028 & 2029 & 2030 \\
\hline GHG $_{i=\text { Industry }}$ & 18.5 & 17.6 & 17.9 & 18.2 & 18.5 & 18.8 & 19.1 & 19.4 & 19.7 & 20.0 & 20.4 & 20.7 \\
\hline $\mathrm{GHG}_{i=\text { Building }}$ & 13.7 & 13.4 & 13.6 & 13.9 & 14.2 & 14.5 & 14.7 & 15.0 & 15.3 & 15.6 & 15.9 & 16.2 \\
\hline $\mathrm{GHG}_{i=\text { Travel }}$ & 4.2 & 3.0 & 3.2 & 3.3 & 3.5 & 3.7 & 3.8 & 4.0 & 4.1 & 4.3 & 4.4 & 4.6 \\
\hline $\mathrm{GHG}_{i=\text { Transport }}$ & 6.2 & 4.4 & 4.6 & 4.9 & 5.1 & 5.3 & 5.6 & 5.8 & 6.0 & 6.3 & 6.5 & 6.7 \\
\hline $\mathrm{GHG}_{i=\text { Agriculture }}$ & 6.7 & 6.8 & 7.0 & 7.1 & 7.3 & 7.4 & 7.6 & 7.7 & 7.9 & 8.1 & 8.3 & 8.4 \\
\hline $\mathrm{GHG}_{i=\text { Land use }}$ & 5.4 & 5.4 & 5.4 & 5.5 & 5.5 & 5.6 & 5.6 & 5.6 & 5.7 & 5.7 & 5.8 & 5.5 \\
\hline $\mathrm{GHG}_{i=\text { Waste }}$ & 1.7 & 1.7 & 1.8 & 1.8 & 1.8 & 1.9 & 1.9 & 1.9 & 2.0 & 2.0 & 2.1 & 2.1 \\
\hline $\mathrm{GHG}_{i=\text { Internet }}$ & 1.06 & 1.08 & 1.08 & 1.07 & 1.07 & 1.08 & 1.09 & 1.14 & 1.22 & 1.33 & 1.48 & 1.71 \\
\hline $\mathrm{GHG}_{i=\text { Electricity }}$ & \multicolumn{12}{|c|}{ Part of (embedded) all sectors } \\
\hline $\begin{array}{c}\text { Total GHG } \\
\text { Supply (TAGGHGS } \\
\text { without } \\
\text { withe } \\
\text { GHG }_{i-\text { internet }} \\
\text { and internet } \\
\text { handprint }(\mathrm{Gt})\end{array}$ & 56.4 & 52.4 & 53.5 & 54.7 & 55.9 & 57.1 & 58.3 & 59.5 & 60.8 & 62.0 & 63.3 & 64.6 \\
\hline
\end{tabular}

Equation (1) below shows TAGGHGS in year $\mathrm{t}$ :

$$
\text { TAGGHGS }_{t}=\sum_{i} \mathrm{GHG}_{i, t} .
$$

Equation (2) below shows the total global handprint of ICT Solution $\mathrm{j}$ in year $\mathrm{t}$ :

$$
\mathrm{ICT}_{h p, t}=\sum_{j, i} \mathrm{MVCV}_{j, i, t} \times F_{j, i, t} \times \mathrm{GHG}_{i, t} .
$$

where, TAGGHGS $_{t}=$ Total anthropogenic GHG supply in year $t ; \mathrm{GHG}_{i, t}=$ Anthropogenic GHG supply from Sector type $i$ in year $t$; $\mathrm{ICT}_{h p, t}=\mathrm{ICT}$ Solutions total global GHG handprint in year $t ; j=$ ICT Solution type; $i=$ Sector type; $t=$ year; $\mathrm{MVCV}_{j, i, t}=$ Marginal Variable Change Vector of ICT Solution $j$ in Sector $i$ in year $t$; $\mathrm{F}_{j, i, t}=$ Fraction of Sector $i$ which is applicable to ICT Solution $j$ in year $t$.

Here follows two examples which explain somewhat (2);

- In 2030, F is 0.1 for Travel Sector for "Video/telemeeting, air" as it is assumed that $10 \%$ of the Travel sector GHG supply are air travel GHG supply which can be reduced $(50 \%$, MVCV $=0.5)$ via "Video/telemeeting, air" ICT solutions. The minimum values for this case are $\mathrm{F}=0.01$ and $\mathrm{MVCV}=0.05$.

- In 2030, F is 0.5 for Building Sector for "Smart metering in Buildings" as it is assumed that $50 \%$ of the Building sector GHG supply are electricity related GHG supply which can be reduced $(10 \%, M V C V=$ 0.1 ) via "Smart metering in Buildings" ICT solutions. The minimum values for this case are $F=0.05$ and $\mathrm{MVCV}=0.01 . \mathrm{MVCV}_{\text {Smart metering, Buildings, } 2020=0.03}$ is reported in literature [21].

\subsection{Division of GHG supply between electricity and other sources for Industry, Buildings, Travel and Transports}

Table 2 shows that the GHG supply from Industry is $\approx 18 \mathrm{Gt}$ in 2020 with around 6 Gt related to electricity demand. 
Table 3. Division of GHG supply between electricity and other sources between 2020 and 2030

\begin{tabular}{|c|c|c|c|c|c|c|c|c|c|c|c|c|}
\hline & 2019 & 2020 & 2021 & 2022 & 2023 & 2024 & 2025 & 2026 & 2027 & 2028 & 2029 & 2030 \\
\hline $\begin{array}{c}\text { Industry } \\
\text { Electricity } \\
\text { GHG, Gt } \\
\text { CO2e }\end{array}$ & 6.2 & 6.2 & 6.2 & 6.3 & 6.3 & 6.3 & 6.4 & 6.4 & 6.4 & 6.5 & 6.5 & 6.5 \\
\hline $\begin{array}{c}\text { Industry } \\
\text { Electricity } \\
\text { Use, TWh }\end{array}$ & 12000 & 11400 & 11500 & 11600 & 11700 & 11800 & 1190 & 12000 & 12100 & 12200 & 12300 & 12400 \\
\hline $\begin{array}{l}\text { Industry } \\
\text { Others, } \\
\text { Gt CO2e }\end{array}$ & 12.0 & 11.4 & 11.7 & 11.9 & 12.2 & 12.5 & 12.8 & 13.0 & 13.3 & 13.6 & 13.8 & 14.1 \\
\hline $\begin{array}{c}\text { Buildings } \\
\text { Electricity } \\
\text { GHG, Gt } \\
\text { CO2e }\end{array}$ & 6.7 & 7.1 & 7.2 & 7.4 & 7.6 & 7.8 & 7.9 & 8.1 & 8.3 & 8.5 & 8.7 & 8.3 \\
\hline $\begin{array}{l}\text { Buildings } \\
\text { Electricity } \\
\text { Use, TWh }\end{array}$ & 12300 & 13000 & 13370 & 13740 & 14110 & 14480 & 14850 & 15220 & 15590 & 15960 & 16330 & 16700 \\
\hline $\begin{array}{l}\text { Buildings } \\
\text { Others, } \\
\text { Gt CO2e }\end{array}$ & 7.0 & 6.3 & 6.4 & 6.5 & 6.6 & 6.7 & 6.8 & 6.9 & 7.0 & 7.1 & 7.2 & 7.3 \\
\hline $\begin{array}{c}\text { Travel } \\
\text { Electricity } \\
\text { GHG, Gt } \\
\text { CO2e }\end{array}$ & 0.2 & 0.2 & 0.3 & 0.3 & 0.4 & 0.5 & 0.5 & 0.6 & 0.6 & 0.7 & 0.7 & 0.8 \\
\hline $\begin{array}{c}\text { Travel } \\
\text { Electricity } \\
\text { Use, TWh }\end{array}$ & 400 & 400 & 510 & 620 & 730 & 840 & 950 & 1060 & 1170 & 1280 & 1390 & 1500 \\
\hline $\begin{array}{c}\text { Travel } \\
\text { Others, } \\
\text { Gt } \\
\text { CO2e }\end{array}$ & 4.0 & 2.8 & 2.9 & 3.0 & 3.1 & 3.2 & 3.3 & 3.4 & 3.5 & 3.6 & 3.7 & 3.8 \\
\hline $\begin{array}{c}\text { Transports } \\
\text { Electricity, } \\
\text { GHG, Gt, } \\
\text { CO2e }\end{array}$ & 0.2 & 0.2 & 0.2 & 0.3 & 0.3 & 0.3 & 0.4 & 0.4 & 0.4 & 0.5 & 0.5 & 0.5 \\
\hline $\begin{array}{c}\text { Transports } \\
\text { Power, } \\
\text { TWh }\end{array}$ & 400 & 400 & 460 & 520 & 580 & 640 & 700 & 760 & 820 & 880 & 940 & 1000 \\
\hline $\begin{array}{l}\text { Transports } \\
\text { Others, } \\
\text { Gt CO2e }\end{array}$ & 6.0 & 4.2 & 4.4 & 4.6 & 4.8 & 5 & 5.2 & 5.4 & 5.6 & 5.8 & 6 & 6.2 \\
\hline $\begin{array}{c}\text { Internet } \\
\text { Electricity } \\
\text { GHG, Gt } \\
\text { CO2e }\end{array}$ & 1.1 & 1.1 & 1.1 & 1.1 & 1.1 & 1.1 & 1.1 & 1.1 & 1.2 & 1.3 & 1.5 & 1.7 \\
\hline $\begin{array}{c}\text { Internet } \\
\text { Electricity } \\
\text { Use, TWh }\end{array}$ & 1950 & 1988 & 1986 & 1987 & 1997 & 2015 & 2046 & 2139 & 2288 & 2493 & 2791 & 3218 \\
\hline $\begin{array}{c}\text { TOTAL } \\
\text { GLOBAL } \\
\text { CO2e from } \\
\text { human energy } \\
\text { conversion } \\
\text { activities, } \\
\text { Gt CO2e }\end{array}$ & 43.7 & 39.5 & 40.4 & 41.4 & 42.4 & 43.3 & 44.3 & 45.4 & 46.4 & 47.5 & 48.7 & 49.9 \\
\hline
\end{tabular}


Transport Electricity GHG and Travel Electricity GHG are both $\approx 6 \%$ of respective Sectors total GHG, while Land use Electricity GHG is excluded as it is assumed close to zero. However, with the anticipated electrification of vehicles, both Transport and Travel Electricity GHG will increase [17].

Moreover, hydrogen production for fuel cell vehicles - and indirectly ammonia production for internal combustion engines - will add to the electricity demand of the Transport and Travel Sectors [13]. Hydrogen production will also add electricity demand in the Industry sector (e.g. Steel supply chain), but at the same time the net GHG supply may be reduced in e.g. Steel production [13].

Ammonia has potential for Travel and Transport as a more or less non-ICT based GHG Supply reducer as ammonia can be used in converted internal combustion engines [22]. It is especially useful to know Industry Electricity Use and Building Electricity Use to understand the effectiveness of different electrical energy efficiency strategies such as Smart Metering. Internet also has some GHG supply from other sources than electricity, such as from diesel generators [23] but they have been excluded. Table 3 shows the split between electricity GHG and other sources for each Sector.

Table 3 may help understand where electrification, hydrogen and ammonia solutions make the most sense in energy related activities.

\subsection{Estimation of ICT Solutions handprints}

They key question addressed here is: How much GHG supply can smart ICT Solutions help avoid, ICT $T_{h p, t}$, in other sectors of society each year between $t=2019$ and $t=2030$ ? Despite large uncertainties, quite likely


for $t=2022$. Table 4 shows the addressed Fraction (F) of each Sector (i) and how much the ICT technology (j) can reduce (MVCV).

Table 5 roughly outlines how $\mathrm{ICT}_{h p, t}$ could increase year by year from 2019 to 2030 as estimated in the present study to reach (at the most) $\approx 11 \mathrm{Gt}$ in 2030 . However, likely some reduction of TAGGHGS has already occurred historically due to ICT solutions and sensitivity checks are performed in Section 4. Table 5 shows mainly future potential to 2030. In Sections 2.5 .1 to 2.5.9 the numbers in Table 5 are explained.

Table 6 outlines roughly how electricity handprints (TWh) could increase linearly year by year from 2020 to 2030 as estimated in the present study to reach $\approx 8497$ TWh in 2030. As soon as 2022 more TWh can be cut by the Internet than its own usage.

\subsubsection{Smart Grid}

Table 7 shows three examples of where Smart Grid can achieve transformation. Smart Grid savings are firstly that $50 \%$ of all Buildings GHG supply are applicable for $10 \%$ reduction each using Smart Metering. This means that $0.1 \times 0.5 \times 16.2 \mathrm{Gt}=0.81 \mathrm{Gt}$ can be avoided in 2030. Smart Metering makes the users aware of the power consumption [21]. Smart Grid savings can also be obtained from "Power grid optimization" which may reduce $50 \%$ (power load balancing) of power use in each case it is introduced, but perhaps only $10 \%$ of global electricity GHG supply is applicable for optimization in 2030, i.e., $0.5 \times 0.1 \times 34718 \mathrm{TWh} \times 0.000533 \mathrm{Gt} / \mathrm{TWh}=$ $0.92 \mathrm{Gt}$.

Further Smart Grid related savings by fewer losses than traditional grids [26] are possible from facilitation of renewable energy sources. This is assumed to reduce $10 \%$ of the power used in each applicable case which may be $20 \%$ of all globally used electricity, $0.1 \times 0.2 \times 34718 \mathrm{TWh} \times 0.000533 \mathrm{Gt} / \mathrm{TWh}=0.37 \mathrm{Gt}$. AI-driven battery management (including self-repair) is part of the renewable energy story for ICT handprint. All in all in 2030, $0.81+0.92+0.37=2.1$ Gt savings in 2030 from Smart Grid.

\subsubsection{Smart Agriculture}

Table 8 shows an example in which Smart Agriculture can achieve transformation. Smart Agriculture can be used to reduce TAGGHGS by e.g. more surveillance and less manual inspection. It is estimated that $10 \%$ of GHG supply of the entire Agriculture sector can be reduced, $0.10 \times 8.43 \mathrm{Gt}=0.84 \mathrm{Gt}$. AI is especially useful in Agriculture [28]. Autonomous variable herbicide spraying can save $>50 \%$ of liquid applied per hectare [29]. 
Table 4. Evolution matrix for F and MVCV for $t=2019$ to 2030 for chosen $i$ and $j$.

\begin{tabular}{|c|c|c|c|c|c|c|c|c|c|c|c|c|c|}
\hline$\# j$ & 2019 & 2020 & 2021 & 2022 & 2023 & 2024 & 2025 & 2026 & 2027 & 2028 & 2029 & 2030 & $\begin{array}{l}\text { MVC } \\
v, j\end{array}$ \\
\hline 1 & 0.005 & 0.05 & 0.1 & 0.2 & 0.3 & 0.4 & 0.5 & 0.6 & 0.7 & 0.8 & 0.9 & 1 & $10 \%$ \\
\hline 2 & 0.0001 & 0.001 & 0.02 & 0.04 & 0.06 & 0.08 & 0.1 & 0.12 & 0.14 & 0.16 & 0.18 & 0.2 & $10 \%$ \\
\hline 3 & 0.00005 & 0.0005 & 0.01 & 0.02 & 0.03 & 0.04 & 0.05 & 0.06 & 0.07 & 0.08 & 0.09 & 0.1 & $20 \%$ \\
\hline 4 & 0.00025 & 0.0025 & 0.05 & 0.1 & 0.15 & 0.2 & 0.25 & 0.3 & 0.35 & 0.4 & 0.45 & 0.5 & $10 \%$ \\
\hline 5 & 0.005 & 0.05 & 0.1 & 0.2 & 0.3 & 0.4 & 0.5 & 0.6 & 0.7 & 0.8 & 0.9 & 1 & $10 \%$ \\
\hline 6 & 0.005 & 0.05 & 0.1 & 0.2 & 0.3 & 0.4 & 0.5 & 0.6 & 0.7 & 0.8 & 0.9 & 1 & $10 \%$ \\
\hline 7 & 0.0005 & 0.005 & 0.01 & 0.02 & 0.03 & 0.04 & 0.05 & 0.06 & 0.07 & 0.08 & 0.09 & 0.1 & $10 \%$ \\
\hline 8 & 0.0005 & 0.005 & 0.01 & 0.02 & 0.03 & 0.04 & 0.05 & 0.06 & 0.07 & 0.08 & 0.09 & 0.1 & $20 \%$ \\
\hline 9 & 0.0025 & 0.025 & 0.05 & 0.1 & 0.15 & 0.20 & 0.25 & 0.3 & 0.35 & 0.4 & 0.45 & 0.5 & $20 \%$ \\
\hline 10 & 0.01 & 0.1 & 0.1 & 0.1 & 0.1 & 0.1 & 0.1 & 0.1 & 0.1 & 0.1 & 0.1 & 0.1 & $50 \%$ \\
\hline 11 & 0.01 & 0.1 & 0.1 & 0.1 & 0.1 & 0.1 & 0.1 & 0.1 & 0.1 & 0.1 & 0.1 & 0.1 & $50 \%$ \\
\hline 12 & 0.005 & 0.05 & 0.01 & 0.02 & 0.03 & 0.04 & 0.05 & 0.06 & 0.07 & 0.08 & 0.09 & 0.1 & $20 \%$ \\
\hline 13 & 0.001 & 0.01 & 0.02 & 0.04 & 0.06 & 0.08 & 0.10 & 0.12 & 0.14 & 0.16 & 0.18 & 0.2 & $50 \%$ \\
\hline 14 & 0.00005 & 0.0005 & 0.001 & 0.002 & 0.003 & 0.004 & 0.005 & 0.006 & 0.007 & 0.008 & 0.009 & 0.01 & $10 \%$ \\
\hline 15 & 0.0015 & 0.015 & 0.03 & 0.06 & 0.09 & 0.12 & 0.15 & 0.18 & 0.21 & 0.24 & 0.27 & 0.3 & $50 \%$ \\
\hline 16 & 0.0005 & 0.005 & 0.01 & 0.02 & 0.03 & 0.04 & 0.05 & 0.06 & 0.07 & 0.08 & 0.09 & 0.1 & $20 \%$ \\
\hline 17 & 0.0025 & 0.025 & 0.05 & 0.1 & 0.15 & 0.2 & 0.25 & 0.3 & 0.35 & 0.4 & 0.45 & 0.5 & $20 \%$ \\
\hline 18 & 0.0005 & 0.005 & 0.01 & 0.02 & 0.03 & 0.04 & 0.05 & 0.06 & 0.07 & 0.08 & 0.09 & 0.1 & $50 \%$ \\
\hline 19 & 0.005 & 0.05 & 0.1 & 0.2 & 0.3 & 0.4 & 0.5 & 0.6 & 0.7 & 0.8 & 0.9 & 1 & $10 \%$ \\
\hline 20 & 0.0005 & 0.005 & 0.01 & 0.02 & 0.03 & 0.04 & 0.05 & 0.06 & 0.07 & 0.08 & 0.09 & 0.1 & $10 \%$ \\
\hline \multicolumn{13}{|c|}{ Name of ICT Solution, $j$} & \#j \\
\hline \multicolumn{13}{|c|}{ Autonomous intelligent tractors help avoid manual checks of the fields of cultivation } & 1 \\
\hline \multirow{2}{*}{\multicolumn{13}{|c|}{ Facilitating renewable energy sources }} & 2 \\
\hline \multirow{2}{*}{\multicolumn{13}{|c|}{$\begin{array}{c}\text { Power grid optimization } \\
\text { Smart metering in Buildings }\end{array}$}} & 3 \\
\hline \multicolumn{8}{|c|}{ Smart metering in Buildings } & & & & & & 4 \\
\hline \multicolumn{13}{|c|}{ Car pools, leasing services, mobility-as-a-service } & 5 \\
\hline \multicolumn{13}{|c|}{ Selling products as services, servitization } & 6 \\
\hline \multicolumn{13}{|c|}{ Public travel suggestions } & 7 \\
\hline \multicolumn{13}{|c|}{ Fleet car management } & 8 \\
\hline \multicolumn{13}{|c|}{ Route optimization in Leisure } & 9 \\
\hline \multicolumn{13}{|c|}{ Video/telemeetings, car } & 10 \\
\hline \multicolumn{13}{|c|}{ Video/telemeetings, air } & 11 \\
\hline \multicolumn{13}{|c|}{ Office space } & 12 \\
\hline \multicolumn{13}{|c|}{ Teleworking, car } & 13 \\
\hline \multicolumn{13}{|c|}{ Hotels } & 14 \\
\hline \multicolumn{13}{|c|}{ Office energy use } & 15 \\
\hline \multicolumn{13}{|c|}{ Food store cooling energy } & 16 \\
\hline \multicolumn{13}{|c|}{ Route optimization in Logistics } & 17 \\
\hline \multicolumn{13}{|c|}{ Facilitate choosing train instead of car } & 18 \\
\hline \multirow{2}{*}{\multicolumn{13}{|c|}{ AI enabled optical sorting }} & 19 \\
\hline & & & & & & & & & & & & & 20 \\
\hline
\end{tabular}


Table 5. Estimation of GHG supply (Gigatonnes) reductions enabled by ICT Solutions 2019-2030.

\begin{tabular}{c|c|c|c|c|c|c|c|c|c|c|c|c} 
& 2019 & 2020 & 2021 & 2022 & 2023 & 2024 & 2025 & 2026 & 2027 & 2028 & 2029 & 2030 \\
\hline $\begin{array}{c}\text { Intelligent Grid } \\
\text { Handprint, Gt }\end{array}$ & 0.00 & 0.01 & 0.17 & 0.35 & 0.54 & 0.74 & 0.94 & 1.15 & 1.37 & 1.60 & 1.85 & 2.11 \\
\hline $\begin{array}{c}\text { Intelligent } \\
\text { Agriculture } \\
\text { Handprint, Gt }\end{array}$ & 0.00 & 0.03 & 0.07 & 0.14 & 0.22 & 0.30 & 0.38 & 0.46 & 0.55 & 0.65 & 0.74 & 0.84 \\
\hline $\begin{array}{c}\text { Intelligent Service } \\
\text { Handprint, Gt }\end{array}$ & 0.01 & 0.10 & 0.21 & 0.43 & 0.66 & 0.90 & 1.15 & 1.40 & 1.67 & 1.95 & 2.23 & 2.53 \\
\hline $\begin{array}{c}\text { Intelligent Travel } \\
\text { Handprint, Gt }\end{array}$ & 0.00 & 0.02 & 0.04 & 0.09 & 0.14 & 0.19 & 0.25 & 0.31 & 0.38 & 0.45 & 0.52 & 0.60 \\
\hline $\begin{array}{c}\text { Intelligent Work } \\
\text { Handprint, Gt }\end{array}$ & 0.05 & 0.33 & 0.38 & 0.46 & 0.54 & 0.63 & 0.73 & 0.82 & 0.93 & 1.03 & 1.14 & 1.26 \\
\hline $\begin{array}{c}\text { Intelligent } \\
\text { Buildings } \\
\text { Handprint, Gt }\end{array}$ & 0.01 & 0.11 & 0.23 & 0.47 & 0.72 & 0.98 & 1.25 & 1.53 & 1.82 & 2.12 & 2.43 & 2.75 \\
\hline $\begin{array}{c}\text { Intelligent } \\
\text { Transport } \\
\text { Handprint, Gt }\end{array}$ & 0.00 & 0.03 & 0.07 & 0.15 & 0.23 & 0.32 & 0.42 & 0.52 & 0.63 & 0.75 & 0.88 & 1.01 \\
\hline $\begin{array}{c}\text { Intelligent } \\
\text { Circularity } \\
\text { Handprint, Gt }\end{array}$ & 0.00 & 0.01 & 0.02 & 0.04 & 0.05 & 0.07 & 0.10 & 0.12 & 0.14 & 0.16 & 0.19 & 0.21 \\
\hline $\begin{array}{c}\text { Intelligent Land } \\
\text { Use Handprint, Gt }\end{array}$ & 0.00 & 0.00 & 0.01 & 0.01 & 0.02 & 0.02 & 0.03 & 0.03 & 0.04 & 0.05 & 0.06 & 0.5 \\
\hline $\begin{array}{c}\text { TOTAL SMART } \\
\text { savings per year } \\
\text { ICT }\end{array}$ (ap & 0.08 & 0.65 & 1.20 & 2.14 & 3.12 & 4.16 & 5.23 & 6.35 & 7.53 & 8.75 & 10.03 & 11.37
\end{tabular}

Table 6. Estimation of electricity handprint (TWh) enabled by ICT Solutions 2019-2030.

\begin{tabular}{c|c|c|c|c|c|c|c|c|c|c|c|c} 
& 2019 & 2020 & 2021 & 2022 & 2023 & 2024 & 2025 & 2026 & 2027 & 2028 & 2029 & 2030 \\
\hline Industry & 1201 & 1150 & 1345 & 1559 & 1781 & 2014 & 2256 & 2510 & 2776 & 3058 & 3356 & 3376 \\
\hline Buildings & 12 & 127 & 322 & 662 & 1020 & 1396 & 1789 & 2201 & 2630 & 3077 & 3542 & 4025 \\
\hline Travel & 4.7 & 47 & 68 & 103 & 145 & 195 & 252 & 316 & 387 & 466 & 552 & 645 \\
\hline Transports & 0.3 & 3.0 & 6.9 & 16 & 26 & 38 & 53 & 68 & 86 & 106 & 127 & 150 \\
\hline $\begin{array}{c}\text { TOTAL savings } \\
\text { TWh }\end{array}$ & 1218 & 1327 & 1742 & 2339 & 2973 & 3643 & 4349 & 5095 & 5880 & 6706 & 7577 & 8497
\end{tabular}

Table 7. Smart Grid saving ICT Technologies

\begin{tabular}{c|c|c|c|c}
$\mathrm{t}=2030$ & & $\mathrm{i}$ & Buildings & Global electricity supply \\
\hline $\mathrm{j}$ & $\mathrm{MVCV}$ & & $\mathrm{F}$ & \\
\hline Facilitating renewable energy sources & $10 \%[24]$ & & $20 \%[24]$ \\
\hline Power grid optimization & $50 \%[24]$ & & & $10 \%[24]$ \\
\hline Smart metering in Buildings & $10 \%[25]$ & & $50 \%[25]$ &
\end{tabular}

Table 8. Smart Agriculture saving ICT technologies

\begin{tabular}{c|c|c}
$t=2030$ & $i$ & Agriculture \\
\hline$j$ & MVCV & F \\
\hline $\begin{array}{c}\text { Autonomous intelligent tractors help avoid } \\
\text { manual checks of the fields of cultivation }\end{array}$ & $10 \%[27]$ & $100 \%[27]$
\end{tabular}




\subsubsection{Smart Services}

Smart Services is a rather wide concept for Smart ICT but mainly it is about virtualization and dematerialization. The link to servitization is very strong [29,30]. Table 9 shows two examples in which Smart Services can achieve transformation.

Table 9. Smart Services saving ICT Technologies.

\begin{tabular}{c|c|c|c|c}
$t=2030$ & & $i$ & Travel & Industry \\
\hline$j$ & MVCV & & $\mathrm{F}$ & $\mathrm{F}$ \\
\hline Car pools, leasing services, mobility-as-a-service & $10 \%[30]$ & $100 \%[30]$ & \\
\hline Selling products as services, servitization & $10 \%[31]$ & & $100 \%[30]$
\end{tabular}

E-readers and audio books are examples of book-as-a-service (potentially) replacing physical books [8]. Global Change Mix Factors [32] may reveal to which degree this will materialize and then cause a rebound effect on F. Regarding financial products, digital solutions on blockchain may change the electricity demand of the financial systems [33]. Another example of smart service is e-commerce [34]. With the current rate of digitalization it seems likely that $100 \%$ of all Industry products could be sold as services in 2030. It is assumed that $10 \%$ of all travel transport and $10 \%$ of all Industry GHG supply can be avoided by selling products as services. All in all, $0.1 \times 1 \times 4.6 \mathrm{Gt}+0.1 \times 1 \times 20.7 \mathrm{Gt}=2.5 \mathrm{Gt}$.

\subsubsection{Smart Travel}

Smart Travel is about optimizing travel routes and vehicle sharing. It is assumed that three main mechanisms lead to savings; smart public travel, fleet car management and route optimization. Table 10 shows two examples in which Smart Travel solutions can achieve transformation.

Table 10. Smart Travel saving ICT Technologies

\begin{tabular}{c|c|c|c}
$t=2030$ & & $i$ & Travel \\
\hline$j$ & MVCV & & F \\
\hline Public travel suggestions & $10 \%[35]$ & $10 \%[35]$ \\
\hline Fleet car management & $20 \%[36]$ & $10 \%[36]$ \\
\hline Route optimization in Leisure & $20 \%[37]$ & $50 \%[37]$
\end{tabular}

AI Taxi is an example of fleet car management [7]. The eighth and ninth handprints may be overestimated. Map route travel service handprints are already achieved. All in all, Smart Travel may reduce GHG supply by $(0.1 \times 0.1+0.2 \times 0.1+0.2 \times 0.5) \times 4.6 \mathrm{Gt}=0.6 \mathrm{Gt}$.

\subsubsection{Smart Work}

Smart Work is about reducing business travel and commuting and the need for less hotel rooms and offices. In 2020 the airline passenger traffic shrunk 67\% compared to 2019 and was reduced to 1999 levels [38]. No matter the reason, this suggests that digitalization tools could reach a very high implementation (high F) for video/telemeetings already in 2020 (Table 4). Table 11 shows five examples in which Smart Work solutions can achieve transformation.

Table 11. Smart Services saving ICT Technologies.

\begin{tabular}{c|c|c|c|c}
$t=2030$ & & $i$ & Travel & Buildings \\
\hline$j$ & MVCV & F & F \\
\hline Video/telemeetings, air & $50 \%[39]$ & & $10 \%[30]$ & \\
\hline Video/telemeetings, car & $50 \%[40]$ & & $10 \%[40]$ & \\
\hline Teleworking, car & $50 \%[41]$ & & $20 \%[41]$ & \\
\hline Office space & $20 \%[42]$ & & $100 \%[30]$ \\
\hline Hotels & $10 \%[43]$ & & & $1 \%[43]$
\end{tabular}


The tenth and eleventh services could be similar and double counted. A sensitivity analysis will include such issues. All in all, Smart Work may reduce GHG supply by $(0.5 \times 0.1+0.5 \times 0.1+0.5 \times 0.2) \times 4.6 \mathrm{Gt}+$ $(0.2 \times 0.1+0.1 \times 0.01) \times 16.2 \mathrm{Gt}=1.26 \mathrm{Gt}$.

\subsubsection{Smart Buildings}

Smart ICT is facilitating automated heating, ventilation and air conditioning (HVAC) systems as well as light control. Via deep learning and cloud-based computing, ICT solutions autonomously optimizes existing HVAC control systems for lowest possible energy consumption. Table 12 shows two examples in which Smart Building solutions can achieve transformation.

Table 12. Smart Building saving ICT solutions

\begin{tabular}{c|c|c|c}
$t=2030$ & & $i$ & Buildings \\
\hline$j$ & MVCV & & F \\
\hline Office energy use & $50 \%[39]$ & $30 \%[44]$ \\
\hline Food storage cooling energy & $20 \%[40]$ & $10 \%[45]$
\end{tabular}

Office energy use here, and Smart metering in Section 2.5.1, may address somewhat similar flows. HVAC savings are however also related to thermal energy and not only electricity. All in all, Smart Building solutions may reduce GHG supply by $(0.5 \times 0.3+0.2 \times 0.1) \times 16.2 \mathrm{Gt}=2.75 \mathrm{Gt}$.

\subsubsection{Smart transports}

Smart Transports is mainly about optimization of truck logistics and shifting transport from e.g. car to train [46]. Table 13 shows two examples in which Smart Transport solutions can achieve transformation.

Table 13. Smart Transport saving solutions

\begin{tabular}{c|c|c|c}
$t=2030$ & & $i$ & Transport \\
\hline$j$ & MVCV & & $\mathrm{F}$ \\
\hline Route optimization in Logistics & $20 \%[47]$ & & $50 \%[47]$ \\
\hline Facilitate choosing train instead of truck & $50 \%[48]$ & $10 \%[48]$
\end{tabular}

All in all Smart Transport solutions may reduce GHG supply by $(0.2 \times 0.5+0.5 \times 0.1) \times 4.5 \mathrm{Gt}=0.68 \mathrm{Gt}$. Arguably F for ICT solution (Table 13, last row) may be lower than 10\%. Another example of a Smart Transport solution is wireless vehicle-vehicle communication with Cooperative Adaptive Cruise Control which saves truck fuel [49].

\subsubsection{Smart Circularity}

Around $99 \%$ of everything that we buy becomes waste after 6 months. Some 2 billion tonnes of waste (garbage) is generated annually of which $\approx 2.5 \%$ is e-waste. Total Material Consumption per capita is also increasing. The effective material flow is much higher than the conventional weight flow. The so called Total Material Requirements per $\mathrm{kg}$ metal is increasing, i.e., the ore grades are diminishing. Ore grades (e.g. copper) is gradually decreasing $2.5 \%$ per annum, while production and energy consumption (and GHG supply) from mining is increasing [50]. Using AI software for optimization is likely a more fruitful route than new waste management technologies. In product design, AI may predict product design variables for GHG supply reduction and customer relevance. AI can help the Waste sector by Smart logistics (improvements in route planning), mobile collection of e-waste on demand [51], and via intelligent optical sorting machines.

Here the example of intelligent Optical sorting machines is used to exemplify how much the GHG supply from the Waste Management Sector can be reduced. AI helps capturing data from optical sorters from which machinery can learn and "make" decisions that optimize sorting [52]. AI-Powered Robot Picking is another example of Intelligent Circularity. Smart Circularity can be used in Waste Management to avoid GHG supply. Waste can be identified for its proper handling. It is assumed that in each case Smart Circularity is used 10\% of 
the GHG supply can be avoided and that all waste related GHG supply can be addressed by intelligent sorting in 2030, i.e., $0.1 \times 1 \times 2.1 \mathrm{Gt}=0.21 \mathrm{Gt}$. One could argue that selling services instead of products is also smart circularity [31]. Nevertheless, Industry related material savings (servitization) is addressed by Smart Services in Section 2.5.3.

Route planning of garbage trucks is addressed by Smart Transport in Section 2.5.7. Table 14 shows an example in which a Smart waste management solution can achieve transformation.

Table 14. Smart Waste management solutions

\begin{tabular}{c|c|c|c}
$t=2030$ & & $i$ & Transport \\
\hline$j$ & MVCV & & $\mathrm{F}$ \\
\hline AI enabled optical sorting & $10 \%[52]$ & & $100 \%[52]$
\end{tabular}

All in all Smart Circularity solutions may reduce GHG supply by $0.1 \times 1 \times 2.1 \mathrm{Gt}=0.21 \mathrm{Gt}$.

\subsubsection{Smart land use}

AI can be used for managing sustainable land use [53]. Smart Forestry (IoT monitoring) can be used to reduce GHG supply caused by illegal tree cutting [54,55]. Table 15 shows an example in which a Smart land use solution can achieve transformation.

Table 15. Smart Land use solutions

\begin{tabular}{c|c|c|c}
$t=2030$ & & $i$ & Transport \\
\hline$j$ & MVCV & & F \\
\hline Forest monitoring with drones and sensors & $10 \%[56]$ & & $10 \%[56]$
\end{tabular}

All in all Smart Land use solutions may reduce GHG supply by $0.1 \times 0.1 \times 5.8 \mathrm{Gt}=0.058 \mathrm{Gt}$.

\subsection{Total Internet GHG supply handprint}

All in all, Internet's handprint will be 11.37 Gt in 2030 using assumed (very high) values for MVCV and F. However, when introducing smaller minimum values for MVCV and F, the handprint will be much smaller, but still safely higher than Internet's footprint.

\subsection{Estimation of global GHG supply with and without ICT handprint and Share of electric power GHG of total global GHG}

It is relevant to estimate to which degree the savings from ICT Solutions of Table 5 can reduce TAGGHGS (Table 2). In Table 16 is shown how TAGGHGS is slowed down. In 2020 the TAGGHGS is $0.2 \%$ (57.4 instead of 57.5) less thanks to ICT. In 2030 TAGGHGS could be around 17\% (54.9 instead of 66.3 ) lower than business as usual. Table 16 shows the estimation of global GHG supply with and without ICT handprint and share of electric power GHG supply.

\subsection{Handprint in each Sector}

In this section the savings made possible by Smart Grid, Smart Travel, Smart Buildings etc. are allocated to each societal sector (Table 17). For example the savings by Smart Work are allocated to Travel if the Smart Work savings are travel related, and savings by Smart Grid are allocated to Buildings if the Smart Grid savings are Buildings related.

\subsection{Share of each sectors GHG supply that can be cut by ICT Solutions}

This section discusses the share of each sectors' GHG supply which could be cut year by year from 2019 to 2030. The shares are obtained by dividing the Handprint in the Sector (Table 17) with the Sector (Table 2). Table 18 the shares of each sectors GHG supply that can be cut over time are shown. 
Table 16. Estimation of global GHG supply (Gigatonnes) with and without ICT handprint and Share of electric power GHG, 2019-2030.

\begin{tabular}{c|c|c|c|c|c|c|c|c|c|c|c|c} 
& 2019 & 2020 & 2021 & 2022 & 2023 & 2024 & 2025 & 2026 & 2027 & 2028 & 2029 & 2030 \\
\hline $\begin{array}{c}\text { TAGGHGS (Gt) } \\
\text { without ICT } \\
\text { enabling }\end{array}$ & 57.5 & 53.4 & 54.6 & 55.8 & 57.0 & 58.2 & 59.4 & 60.7 & 62.0 & 63.3 & 64.8 & 66.3 \\
\hline $\begin{array}{c}\text { TAGGHGS (Gt) } \\
\text { thanks to ICT } \\
\text { enabling }\end{array}$ & 57.4 & 52.8 & 53.4 & 53.7 & 53.9 & 54.1 & 54.2 & 54.3 & 54.5 & 54.6 & 54.7 & 54.9 \\
\hline $\begin{array}{c}\text { Global electric } \\
\text { power related } \\
\text { GHG supply }\end{array}$ & 14.7 & 14.8 & 15.1 & 15.4 & 15.7 & 16.0 & 16.3 & 16.6 & 17.0 & 17.5 & 18.0 & 18.5 \\
\hline $\begin{array}{c}\text { Share electric } \\
\text { power CO2e of } \\
\text { TAGGHGS (Gt) } \\
\text { thanks to ICT } \\
\text { enabling }\end{array}$ & $25.7 \%$ & $28.0 \%$ & $28.2 \%$ & $28.6 \%$ & $29.1 \%$ & $29.5 \%$ & $30.0 \%$ & $30.6 \%$ & $31.3 \%$ & $32.0 \%$ & $32.8 \%$ & $33.8 \%$ \\
\hline
\end{tabular}

Table 17. Estimation of global GHG supply (Gigatonnes) with and without ICT handprint and Share of electric power GHG, 2019-2030.

\begin{tabular}{c|c|c|c|c|c|c|c|c|c|c|c|c} 
& 2019 & 2020 & 2021 & 2022 & 2023 & 2024 & 2025 & 2026 & 2027 & 2028 & 2029 & 2030 \\
\hline $\begin{array}{c}\text { Handprint } \\
\text { in Industry }\end{array}$ & 0.01 & 0.09 & 0.28 & 0.58 & 0.88 & 1.20 & 1.53 & 1.86 & 2.22 & 2.58 & 2.96 & 3.37 \\
\hline $\begin{array}{c}\text { Handprint } \\
\text { in Buildings }\end{array}$ & 0.01 & 0.13 & 0.33 & 0.67 & 1.03 & 1.39 & 1.78 & 2.17 & 2.58 & 3.01 & 3.45 & 3.90 \\
\hline $\begin{array}{c}\text { Handprint } \\
\text { in Travel }\end{array}$ & 0.05 & 0.35 & 0.42 & 0.55 & 0.70 & 0.85 & 1.01 & 1.18 & 1.36 & 1.56 & 1.76 & 1.98 \\
\hline $\begin{array}{c}\text { Handprint } \\
\text { in Transports }\end{array}$ & 0.00 & 0.03 & 0.07 & 0.15 & 0.23 & 0.32 & 0.42 & 0.52 & 0.63 & 0.75 & 0.88 & 1.01 \\
\hline $\begin{array}{c}\text { Handprint } \\
\text { in Agriculture }\end{array}$ & 0.00 & 0.03 & 0.07 & 0.14 & 0.22 & 0.30 & 0.38 & 0.46 & 0.55 & 0.65 & 0.74 & 0.84 \\
\hline $\begin{array}{c}\text { Handprint } \\
\text { in Waste }\end{array}$ & 0.00 & 0.01 & 0.02 & 0.04 & 0.05 & 0.07 & 0.10 & 0.12 & 0.14 & 0.16 & 0.19 & 0.21 \\
\hline $\begin{array}{c}\text { Handprint } \\
\text { in Land use }\end{array}$ & 0.00 & 0.00 & 0.01 & 0.01 & 0.02 & 0.02 & 0.03 & 0.03 & 0.04 & 0.05 & 0.05 & 0.06 \\
\hline $\begin{array}{c}\text { TOTAL Internet } \\
\text { handprint per year }\end{array}$ & 0.08 & 0.65 & 1.20 & 2.14 & 3.12 & 4.16 & 5.23 & 6.35 & 7.53 & 8.75 & 10.03 & 11.37
\end{tabular}

Table 18. Shares of each sectors GHG supply that can be cut by ICT Solutions between 2019 and 2030.

\begin{tabular}{c|c|c|c|c|c|c|c|c|c|c|c|c} 
& 2019 & 2020 & 2021 & 2022 & 2023 & 2024 & 2025 & 2026 & 2027 & 2028 & 2029 & 2030 \\
\hline Industry & $0 \%$ & $1 \%$ & $2 \%$ & $3 \%$ & $5 \%$ & $7 \%$ & $9 \%$ & $10 \%$ & $12 \%$ & $14 \%$ & $16 \%$ & $17 \%$ \\
\hline Buildings & $0 \%$ & $1 \%$ & $2 \%$ & $5 \%$ & $7 \%$ & $10 \%$ & $12 \%$ & $14 \%$ & $17 \%$ & $19 \%$ & $22 \%$ & $24 \%$ \\
\hline Travel & $1 \%$ & $12 \%$ & $13 \%$ & $17 \%$ & $20 \%$ & $23 \%$ & $27 \%$ & $30 \%$ & $33 \%$ & $36 \%$ & $40 \%$ & $43 \%$ \\
\hline Transports & $0 \%$ & $1 \%$ & $2 \%$ & $3 \%$ & $5 \%$ & $6 \%$ & $8 \%$ & $9 \%$ & $11 \%$ & $12 \%$ & $14 \%$ & $15 \%$ \\
\hline Agriculture & $0 \%$ & $1 \%$ & $1 \%$ & $2 \%$ & $3 \%$ & $4 \%$ & $5 \%$ & $6 \%$ & $7 \%$ & $8 \%$ & $9 \%$ & $10 \%$ \\
\hline Land use & $0 \%$ & $0 \%$ & $0 \%$ & $0 \%$ & $0 \%$ & $0 \%$ & $1 \%$ & $1 \%$ & $1 \%$ & $1 \%$ & $1 \%$ & $1 \%$ \\
\hline Waste & $0 \%$ & $1 \%$ & $1 \%$ & $2 \%$ & $3 \%$ & $4 \%$ & $5 \%$ & $6 \%$ & $7 \%$ & $8 \%$ & $9 \%$ & $10 \%$
\end{tabular}




\subsection{Effect of Internet handprint on global GHG supply}

In Table 19 the handprint of ICT solutions on TAGGHGS is summarized. In 2030 at the most $\approx 17 \%$ of TAGGHGS (11.37 Gt of $66.3 \mathrm{Gt})$ can be reduced. In Section 4 it is elaborated with sensitivity analysis what speaks for $11.37 \mathrm{Gt}$ and what speaks against.

Table 19. Effect of Internet handprint on global GHG supply from 2019 to 2030.

\begin{tabular}{c|c|c|c|c|c|c|c|c|c|c|c|c} 
& 2019 & 2020 & 2021 & 2022 & 2023 & 2024 & 2025 & 2026 & 2027 & 2028 & 2029 & 2030 \\
\hline $\begin{array}{c}\text { Internet } \\
\text { infrastructure } \\
\text { GHG Supply }\end{array}$ & 1.06 & 1.08 & 1.08 & 1.07 & 1.07 & 1.08 & 1.09 & 1.14 & 1.22 & 1.33 & 1.48 & 1.71 \\
\hline Internet's handprint & 0.08 & 0.65 & 1.20 & 2.14 & 3.12 & 4.16 & 5.23 & 6.35 & 7.53 & 8.75 & 10.03 & 11.37 \\
\hline $\begin{array}{c}\text { Total global GHG } \\
\text { supply without } \\
\text { Internet's handprint }\end{array}$ & 57.5 & 53.4 & 54.6 & 55.8 & 57.0 & 58.2 & 59.4 & 60.7 & 62.0 & 63.3 & 61.8 & 66.3 \\
\hline $\begin{array}{c}\text { Total global GHG } \\
\text { supply with } \\
\text { Internet's handprint }\end{array}$ & 57.4 & 52.8 & 53.7 & 53.9 & 54.1 & 54.2 & 54.3 & 54.5 & 54.6 & 54.6 & 54.7 & 57.9
\end{tabular}

Table 20. Specific ICT Solutions shares of total handprint in 2030.

\begin{tabular}{|c|c|c|c|}
\hline & Effect pathway & Gt CO2e & $\begin{array}{l}\text { Share of handprint } \\
\text { in } 2030\end{array}$ \\
\hline \multicolumn{4}{|l|}{ SMART GRID } \\
\hline Smart metering in Buildings & less energy use & 0.81 & $7.1 \%$ \\
\hline Facilitating renewable energy sources & less energy use & 0.37 & $3.3 \%$ \\
\hline Power grid optimization & less energy use & 0.93 & $8.2 \%$ \\
\hline \multicolumn{4}{|l|}{ SMART AGRICULTURE } \\
\hline $\begin{array}{l}\text { Autonomous intelligent tractors help avoid } \\
\text { manual checks of the fields of cultivation. }\end{array}$ & less material use and land use & 0.84 & $7.4 \%$ \\
\hline \multicolumn{4}{|l|}{ SMART SERVICES } \\
\hline $\begin{array}{l}\text { Car pools, leasing services, } \\
\text { mobility-as-a-service }\end{array}$ & Fuel saving & 0.46 & $4.0 \%$ \\
\hline Products sold as Services & Material efficiency & 2.07 & $18.2 \%$ \\
\hline \multicolumn{4}{|l|}{ SMART TRAVEL } \\
\hline Public travel suggestions & Information availability & 0.05 & $0.4 \%$ \\
\hline Fleet car management & Fuel saving & 0.05 & $0.4 \%$ \\
\hline Route optimization in Leisure & Fuel saving & & $0.8 \%$ \\
\hline \multicolumn{4}{|l|}{ SMART WORK } \\
\hline Video/telemeetings, air & Marginal effect on aviation & 0.23 & $2.0 \%$ \\
\hline Video/telemeetings, car & Fuel saving & 0.23 & $2.0 \%$ \\
\hline Teleworking, car & Fuel saving & 0.46 & $4.0 \%$ \\
\hline Office space & Energy saving & 0.32 & $2.8 \%$ \\
\hline Hotels & Energy saving & 0.02 & $0.1 \%$ \\
\hline \multicolumn{4}{|l|}{ SMART BUILDINGS } \\
\hline Office energy use & Thermal energy saving & 2.43 & $21.4 \%$ \\
\hline Food storage cooling energy & Electric power saving & 0.32 & $2.8 \%$ \\
\hline \multicolumn{4}{|l|}{ SMART TRANSPORT } \\
\hline Route optimization in Logistics & Fuel saving & 0.67 & $5.9 \%$ \\
\hline Facilitate choosing train instead of car & Information availability & 0.34 & $3.0 \%$ \\
\hline \multicolumn{4}{|l|}{ SMART CIRCULARITY } \\
\hline AI enabled optical sorting & Material recycling & 0.21 & $1.8 \%$ \\
\hline \multicolumn{4}{|l|}{ SMART LAND USE } \\
\hline Forest monitoring with drones and sensors & Forestation & 0.06 & $0.05 \%$ \\
\hline TOTAL & & 11.37 & $100 \%$ \\
\hline
\end{tabular}




\subsection{Specific ICT Solution share of total handprint in 2030}

Here specific ICT Solutions are listed in Table 20 and their share of total handprint. The largest reduction amount, $2.43 \mathrm{Gt}$ and $21 \%$, can be achieved from "Office energy use" and "Selling products as services, servitization" $2.07 \mathrm{Gt}$ and $18 \%$.

\subsection{Individual products handprint}

In the present decade there will be an unprecedented growth of generated data shown in Table 21 [16]. This can be used to estimate Internet's handprint per Byte. Individual product's services handprints can then be estimated if their bandwidths are known. Evidently, applicable handprint services need to have specific pathways for creating handprints.

Table 21. Effect of Internet handprint on global GHG supply from 2019 to 2030.

\begin{tabular}{c|c|c|c|c|c|c|c|c|c|c|c|c} 
& 2019 & 2020 & 2021 & 2022 & 2023 & 2024 & 2025 & 2026 & 2027 & 2028 & 2029 & 2030 \\
\hline $\begin{array}{c}\text { Mobile } \\
\text { data } \\
\text { traffic } \\
\text { (EB/year) }\end{array}$ & 354 & 549 & 829 & 1228 & 1825 & 2718 & 4057 & 6175 & 9290 & 13904 & 20767 & 31008 \\
\hline $\begin{array}{c}\text { Fixed } \\
\text { data } \\
\text { traffic } \\
\text { (EB/year) }\end{array}$ & 1964 & 2444 & 3054 & 3829 & 4817 & 6079 & 7693 & 9763 & 12420 & 15836 & 20234 & 25901 \\
\hline $\begin{array}{c}\text { Within } \\
\text { and } \\
\text { between } \\
\text { Data } \\
\text { centers, } \\
\text { (EB/year) }\end{array}$ & 13004 & 16926 & 22011 & 28606 & 37120 & 48094 & 62208 & 80207 & 103278 & 132745 & 170229 & 217689 \\
\hline $\begin{array}{c}\text { Global } \\
\text { Data } \\
\text { Center }\end{array}$ & 15322 & 19919 & 25895 & 33663 & 43762 & 46890 & 73957 & 96145 & 124988 & 162484 & 211230 & 274599 \\
$\begin{array}{c}\text { IP Traffic, } \\
\text { (EB/year) }\end{array}$ & & & & & & & & & & & & \\
\hline
\end{tabular}

\section{Results}

The order of magnitude of the GHG Supply handprint is reasonable. Figure 2 is a graphical representation of the present article. It seems plausible that Internet's handprint will be higher than its footprint. However, 11.37 Gt may be heavily overestimated.

\section{Discussion}

What would overthrow the results in the present research? Are there any new developments since 2015 which would falsify magnificent Internet handprints? What is only theory and what are the facts? Is here Internet's handprint massively exaggerated several times? One obvious issue is to which extent the digitalization has already been achieved, meaning that $\mathrm{F}^{\prime} \mathrm{s}$ max value for $\mathrm{t}=2030$ is already achieved. 2020 meant a huge leap forward in this respect for some ICT Solutions such as "Video/telemeetings, air" and "Video/telemeetings, car". Anyway the reduction of GHG supply observed in 2020 is not really caused by certain ICT solutions. However, they made e.g. working from home possible. Here the view is taken that ICT solutions number 10 and 11 in Table 4 are tested big-scale making the assumed $50 \%$ ( $\mathrm{F}=0.5)$ cut of applicable Transport and Travel GHG Supply between 2019 and 2020 possible.

On the other hand it is not argued that Internet's handprint will lead to absolute smaller TAGGHGS, but rather a slow-down of the increase of TAGGHGS. 2020 will show this fact e.g. with fewer travels and more virtual meetings. 
2020 showed that digital ICT technologies can be widely adopted very quickly. Smart Buildings is a very important area for ICT solution offsetting of TAGGHGS as Buildings use much energy. However, it may be argued that "Smart Metering in Buildings" and "Smart Buildings office energy use reduction" is equal. Also, old buildings may not be able to reduce energy use as much as newly constructed ones. These limitations are considered to be included in the sensitivity analysis in which F and MVCV are reduced 10 times. $\mathrm{MVCV}_{\mathrm{Smart}}$ metering, Buildings,2020 $=0.03$ [20] measurement is a good indication for the reasonableness of $\mathrm{MVCV}_{\text {Smart metering,Buildings,2030 }}=0.1$.

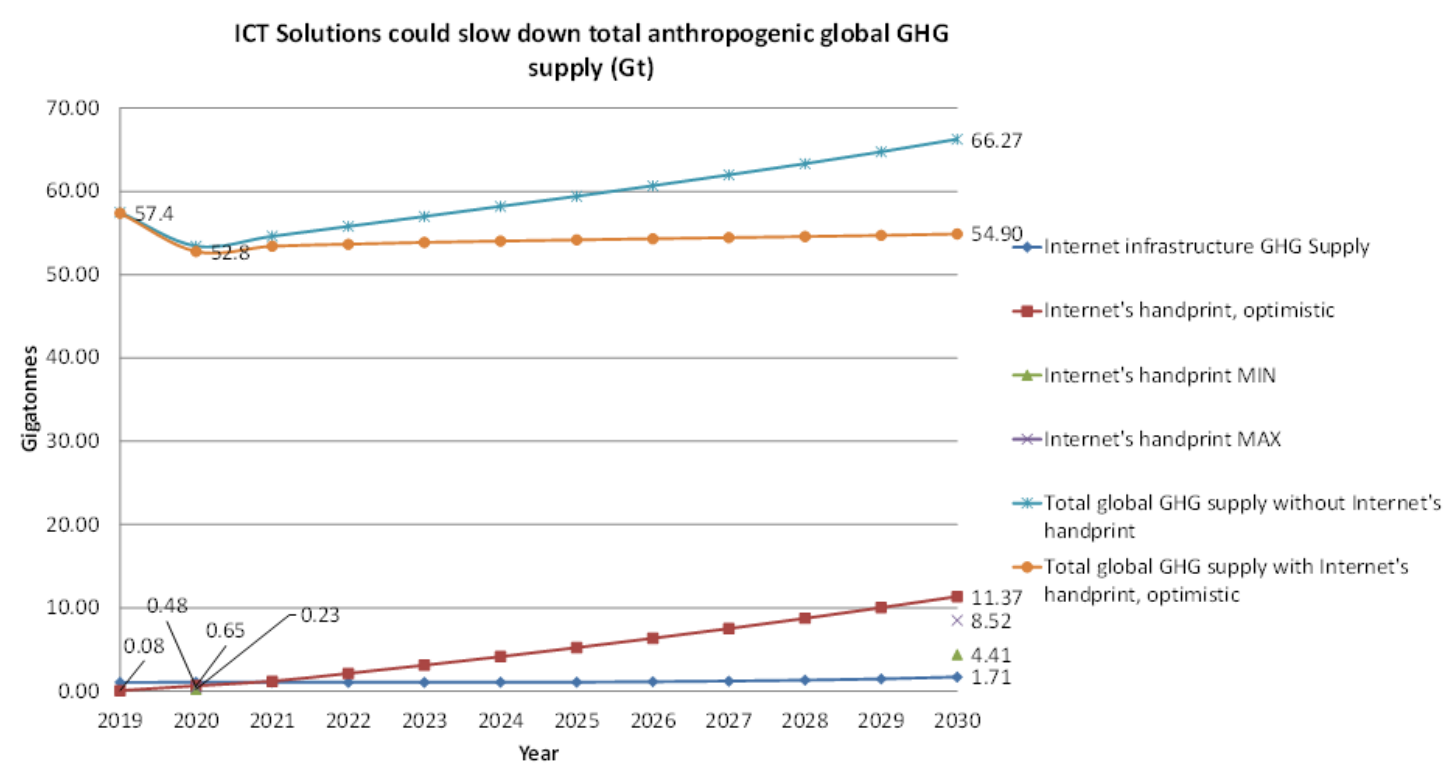

Figure 2. Graphic representation of the effect of ICT Solutions on total anthropogepainic GHG supply

Likewise, certain Smart Travel ICT Solutions may be similar to Smart Services for Travel. Regarding Smart Work ICT Solutions, "telemeeting" and "teleworking" seem identical with regards to Travel handprint.

If the biggest one - teleworking - is churned the total ICT potential is reduced by $0.48 \mathrm{Gt}$ in 2030. Anyway, for Smart Work the anticipated 2030 savings may already have happened in 2020 due to the global macro changes in 2020. Temporary or permanent decline to a new baseline of airline and automotive travel and transport are the most obvious observations in 2020.

The effectiveness of AI to achieve savings depends greatly on sufficient data and the data scientists and engineers developing the AI software. AI has successfully been employed for forecasting the volume of waste which will be generated. This facilitate proper planning of landfill sites, recycling units, development as well as operation of garbage collection infrastructure. AI can cope especially well with historical data which are of nonlinear nature. Still several indications of savings exist.

\section{ICT Product handprints}

What is the link to ICT product related handprints? Dividing the total handprint in Table 5 (11.37 Gt) with the Global Data Center IP Traffic in Table 21 (268 ZettaByte) gives e.g. 0.039 kg CO2e/GigaByte for 2030. However, this intensity is quite rough but may be tested together with specific GigaByte/s bandwidth data.

\section{The right performance for the right application}

What performance is good enough for a certain application? Such questions are valid e.g. for Travel Electricity Use (Table 3) where Na-ion batteries $(90-115 \mathrm{Wh} / \mathrm{kg}$ ) could be enough for certain electric vehicles instead of Li-ion (100-265 Wh/kg) [57,58].

The global material efficiency/waste problem seems not to be solved effectively by improved local waste management (e.g. collection). Perhaps an AI optimization of total global supply chains - which targets waste minimization in production and Total Material Consumption/capita is more effective. Optimizing and predicting the whole nonlinear global societal system with Internet as a driver - markets, Input-Output, GHG 
supply, resources, costs, jobs, waste - is a daunting task which theoretically could better be managed with AI and humans instead of humans alone.

\section{Sensitivity analyses}

Without sensitivity checks by 2030 the handprint/footprint ratio will be around 7 (11.37/1.71). Using Monte Carlo simulation and maximum and minimum values of $\mathrm{F}, \mathrm{MVCV}$ etc. gives an uncertainty spread such that GHGi=Internet, $\mathrm{t}=2020=1.17 \mathrm{Gt}(\mathrm{Min} 1.07 \mathrm{Gt}$ Max 1.29 Gt) and ICThp,2020 = $0.35 \mathrm{Gt}$ (Min $0.23 \mathrm{Gt}$ Max $0.48 \mathrm{Gt})$. All assumptions are found in the Supplementary Information. Videomeetings represent almost $50 \%$ of Internet's handprint in 2020 but just $4 \%$ in 2030 where instead Office energy use and Servitization of products dominate.

Using maximum and minimum values of F, MVCV etc. (see Supplementary Information) gives an uncertainty spread such that $\mathrm{GHG}_{i=\text { Internet, } t=2030}=1.53 \mathrm{Gt}$ (Min 1.28 Gt Max $1.8 \mathrm{Gt}$ ) and $\mathrm{ICT}_{h p, 2030}=6.32$ Gt (Min $4.41 \mathrm{Gt}$ Max $8.52 \mathrm{Gt})$. Compared to the original mean value (11.37 Gt), including the spread of input values reduces the mean value of $\mathrm{ICT}_{h} p, 2030$ substantially due to ten times lower minimum values of $\mathrm{F}$ and MVCV. In 2020 the GHG supply by the Internet is some 70\% higher than Internet's handprint. Hence, the GHG supply by the Internet is not off-set already in 2020 by ICT Solutions. Nevertheless, the handprint/footprint ratio will be around $4(6.32 / 1.53)$ by 2030. Thus the handprint hypotheses in Section 1.2 are falsified.

\section{Next steps}

The present research confirms that the largest handprints from the Internet in 2030 will be in Buildings and Industry. Still, individual nations and service providers would like to estimate better specific handprints. Moreover, the measurable entities in the system should be identified more carefully for individual ICT Solutions such those related to 5G [59]. Additionally, the standardization of the handprint calculation for electronic products should be attempted.

Conflicts of Interest: "The author declares no conflict of interest."

\section{References}

[1] Lange, S., Pohl, J., \& Santarius, T. (2020). Digitalization and energy consumption. Does ICT reduce energy demand?. Ecological Economics, 176, 106760.

[2] Mir, U. (2020). Bitcoin and Its Energy Usage: Existing Approaches, Important Opinions, Current Trends, and Future Challenges. KSII Transactions on Internet and Information Systems (TIIS), 14(8), 3243-3256.

[3] Liu, Y., Wei, X., Xiao, J., Liu, Z., Xu, Y., \& Tian, Y. (2020). Energy consumption and emission mitigation prediction based on data center traffic and PUE for global data centers. Global Energy Interconnection, 3(3), 272-282.

[4] Stobbe, L., Nissen, N. F., Druschke, J., Zedel, H., Richter, N., \& Lang, K. D. (2019). Methodology for Modeling the Energy and Material Footprint of Future Telecommunication Networks. In EcoDesign and Sustainability II (pp. 223-238). Springer, Singapore.

[5] Grönman, K., Pajula, T., Sillman, J., Leino, M., Vatanen, S., Kasurinen, H., \& Soukka, R. (2019). Carbon handprintÜAn approach to assess the positive climate impacts of products demonstrated via renewable diesel case. Journal of Cleaner Production, 206, 1059-1072.

[6] Ulucak, R., \& Khan, S. U. D. (2020). Does information and communication technology affect CO2 mitigation under the pathway of sustainable development during the mode of globalization?. Sustainable Development, 28(4), 857-867.

[7] Zhang, X., Shinozuka, M., Tanaka, Y., Kanamori, Y., \& Masui, T. (2021). Forecast of Future Impacts of Using ICT Services on GHG Emissions Reduction and GDP Growth in Japan. In EcoDesign and Sustainability II (pp. 207-222). Springer, Singapore.

[8] Amasawa, E., Ihara, T., \& Hanaki, K. (2018). Role of e-reader adoption in life cycle greenhouse gas emissions of book reading activities. The International Journal of Life Cycle Assessment, 23(9), 1874-1887.

[9] Zhou, X., Zhou, D., Wang, Q., \& Su, B. (2019). How information and communication technology drives carbon emissions: a sector-level analysis for China. Energy Economics, 81, 380-392.

[10] Bieser, J. C., \& Hilty, L. M. (2018). Assessing indirect environmental effects of information and communication technology (ICT): A systematic literature review. Sustainability, 10(8), 2662.

[11] Bieser, J., \& Hilty, L. (2018). Indirect Effects of the Digital Transformation on Environmental Sustainability: Methodological Challenges in Assessing the Greenhouse Gas Abatement Potential of ICT. EPiC Series in Computing, (52), 68-81. 
[12] Andrae, A. S. G. (2019) Prediction studies of electricity use of global computing in 2030. International Journal of Science and Engineering Investigations, 8, 27-33.

[13] Andrae, A. S. G. (2020). Hypotheses for Primary Energy Use, Electricity Use and CO2 Emissions of Global Computing and Its Shares of the Total Between 2020 and 2030. WSEAS Transactions of Power Systems; 15: 50-59.

[14] Grobe, K., \& Jansen, S. (2020). Limits to exponential internet growth. Proceedings of Electronics Goes Green 2020+, 97-104.

[15] Coindesk. (2020). [cited 25 January 2021].

Available from: https://www.coindesk.com/the-last-word-on-bitcoins-energy-consumption.

[16] Andrae, A .S. G. (2020) New perspectives on internet electricity use in 2030. Engineering and Applied Science Letter, 3(2), 19-31.

[17] Andrae, A. S., \& Edler, T. (2015). On global electricity usage of communication technology: trends to 2030. Challenges, 6(1), 117-157.

[18] Sandberg, I. W. (1973). A nonlinear input-output model of a multisectored economy. Econometrica: Journal of the Econometric Society, 1167-1182.

[19] Le Luu, Q., Longo, S., Cellura, M., Riva Sanseverino, E., Cusenza, M. A., Franzitta, V. (2020). A Conceptual Review on Using Consequential Life Cycle Assessment Methodology for the Energy Sector. Energies, 13(12), 3076.

[20] Netherlands Environmental Assessment Agency (2020). [cited 25 January 2021] Available from: http:/ / www.pbl.nl/en/publications/trends-in-global-co2-and-total-greenhouse-gas-emissions-2019-report

[21] Behavioural Insights Team (2020) [cited 17 March 2021] Available from: https://www.bi.team/wp-content/uploads/2020/12/Guidance-on-conducting-energy-consumption-analysis.pdf

[22] Kobayashi, H., Hayakawa, A., Somarathne, K. K. A., \& Okafor, E. C. (2019). Science and technology of ammonia combustion. Proceedings of the Combustion Institute, 37(1), 109-133.

[23] Andrae, A. S. G. (2015). Comparative screening life cycle impact assessment of renewable and fossil power supply for a radio base station site. International Journal of Green Technology, 1, 21-34.

[24] Feinberg, E. (2012). Smart grid optimization. Energy, 2012. [cited 25 January 2021] Available from: https:/ / www.iaria.org/conferences2012/filesICNS12/SmartGridOptimization-Rev1.pdf

[25] Fischer, C. (2008). Feedback on household electricity consumption: a tool for saving energy?. Energy efficiency, 1(1), 79-104.

[26] Bose, B. K. (2017). Artificial intelligence techniques in smart grid and renewable energy systems-Some example applications. Proceedings of the IEEE, 105(11), 2262-2273.

[27] Berenstein, R., Shahar, O. B., Shapiro, A., \& Edan, Y. (2010). Grape clusters and foliage detection algorithms for autonomous selective vineyard sprayer. Intelligent Service Robotics, 3(4), 233-243.

[28] Magomadov, V. S. (2019, December). Deep learning and its role in smart agriculture. In Journal of Physics: Conference Series (Vol. 1399, No. 4, p. 044109). IOP Publishing.

[29] Pérez-Ruiz, M., Gonzalez-de-Santos, P., Ribeiro, A., Fernández-Quintanilla, C., Peruzzi, A., Vieri, M., \& Agüera, J. (2015). Highlights and preliminary results for autonomous crop protection. Computers and Electronics in Agriculture, 110, 150-161.

[30] Fernando, C., Soo, V. K., \& Doolan, M. (2020). Life Cycle Assessment for Servitization: A Case Study on Current Mobility Services. Procedia Manufacturing, 43, 72-79.

[31] ITU-T (2021). L.1024 (01/21) The potential impact of selling services instead of equipment on waste creation and the environment - Effects on global information and communication technology [cited 17 March 2021] Available from: https://www.itu.int/rec/T-REC-L.1024-202101-I.

[32] Andrae, A. S. (2015). Method based on market changes for improvement of comparative attributional life cycle assessments. The International Journal of Life Cycle Assessment, 20(2), 263-275.

[33] Krause, M. J., Tolaymat, T. (2018). Quantification of energy and carbon costs for mining cryptocurrencies. Nature Sustainability, 1(11), 711-718.

[34] Hischier, R. (2018). Car vs. Packaging-A First, Simple (Environmental) Sustainability Assessment of Our Changing Shopping Behaviour. Sustainability, 10(9), 3061.

[35] Ivanov, S. H., \& Webster, C. (2017). Adoption of robots, artificial intelligence and service automation by travel, tourism and hospitality companiesÜa cost-benefit analysis. Artificial Intelligence and Service Automation by Travel, Tourism and Hospitality CompaniesÜA Cost-Benefit Analysis.

[36] Hu, J., Morais, H., Sousa, T., \& Lind, M. (2016). Electric vehicle fleet management in smart grids: A review of services, optimization and control aspects. Renewable and Sustainable Energy Reviews, 56, 1207-1226.

[37] James, J. Q., Yu, W., \& Gu, J. (2019). Online vehicle routing with neural combinatorial optimization and deep reinforcement learning. IEEE Transactions on Intelligent Transportation Systems, 20(10), 3806-3817. 
[38] Businesswire. (2020). [cited 25 January 2021].

Available from: https://www.businesswire.com/news/home/20201228005254/en/.

[39] Chavanne, X., Schinella, S., Marquet, D., Frangi, J. P., \& Le Masson, S. (2015). Electricity consumption of telecommunication equipment to achieve a telemeeting. Applied Energy, 137, 273-281.

[40] Masino, C., Rubinstein, E., Lem, L., Purdy, B., \& Rossos, P. G. (2010). The impact of telemedicine on greenhouse gas emissions at an academic health science center in Canada. Telemedicine and e-Health, 16(9), 973-976.

[41] O'Keefe, P., Caulfield, B., Brazil, W., White, P. (2016). The impacts of telecommuting in Dublin. Research in Transportation Economics, 57, 13-20.

[42] Lupton, P., \& Haynes, B. (2000). Teleworking-the perception-reality gap. Facilities.

[43] Sato, A. (2019). Telework and its effects in Japan. In telework in the 21st century. Edward Elgar Publishing. DOI: $10.4337 / 9781789903751$.

[44] Serra, J., Pubill, D., Antonopoulos, A., \& Verikoukis, C. (2014). Smart HVAC control in IoT: Energy consumption minimization with user comfort constraints. The Scientific World Journal, 2014.

[45] Nugroho, A., Setiadi, R. N., \& Umar, L. (2020, October). Smart Box Development for Food Storage with PCI-Based Temperature PID Control. In Journal of Physics: Conference Series (Vol. 1655, No. 1, p. 012017). IOP Publishing.

[46] Abduljabbar, R., Dia, H., Liyanage, S., \& Bagloee, S. A. (2019). Applications of artificial intelligence in transport: An overview. Sustainability, 11(1), 189.

[47] Ebendt, R., Sohr, A., Touko Tcheumadjeu, L. C., \& Wagner, P. (2010). Utilizing historical and current travel times based on floating car data for management of an express truck fleet. http://hdl.handle.net/10195/37753.

[48] Gössling, S. (2018). ICT and transport behavior: A conceptual review. International journal of sustainable transportation, 12(3), 153-164

[49] McAuliffe, B., Lammert, M., Lu, X. Y., Shladover, S., Surcel, M. D., \& Kailas, A. (2018). Influences on energy savings of heavy trucks using cooperative adaptive cruise control (No. 2018-01-1181). SAE Technical Paper.

[50] Calvo, G., Mudd, G., Valero, A., \& Valero, A. (2016). Decreasing ore grades in global metallic mining: a theoretical issue or a global reality?. Resources, 5(4), 36.

[51] Nowakowski, P., Szwarc, K., \& Boryczka, U. (2018). Vehicle route planning in e-waste mobile collection on demand supported by artificial intelligence algorithms. Transportation Research Part D: Transport and Environment, 63, 1-22.

[52] Harvard Business School. (2020). [cited 25 January 2021] Available from: https:/ / digital.hbs.edu/platform-digit/submission/tomra-potatoes-to-the-right-rocks-to-the-left/

[53] Liu, Y., Tang, W., He, J., Liu, Y., Ai, T., \& Liu, D. (2015). A land-use spatial optimization model based on genetic optimization and game theory. Computers, Environment and Urban Systems, 49, 1-14.

[54] Zou, W., Jing, W., Chen, G., Lu, Y., \& Song, H. (2019). A survey of big data analytics for smart forestry. IEEE Access, 7, 46621-46636.

[55] Lakhwani, K., Gianey, H., Agarwal, N., \& Gupta, S. (2019). Development of IoT for smart agriculture a review. In Emerging trends in expert applications and security (pp. 425-432). Springer, Singapore.

[56] Basse, R. M., Charif, O., \& Bodis, K. (2016). Spatial and temporal dimensions of land use change in cross border region of Luxembourg. Development of a hybrid approach integrating GIS, cellular automata and decision learning tree models. Applied Geography, 67, 94-108.

[57] Palomares, V., Serras, P., Villaluenga, I., Hueso, K. B., Carretero-González, J., \& Rojo, T. (2012). Na-ion batteries, recent advances and present challenges to become low cost energy storage systems. Energy E Environmental Science, 5(3), 5884-5901.

[58] Mogensen, R., Brandell, D., \& Younesi, R. (2016). Solubility of the solid electrolyte interphase (SEI) in sodium ion batteries. ACS Energy Letters, 1(6), 1173-1178.

[59] Huawei (2020). Green 5G: Building a sustainable world. [cited 25 January 2021] Available from: https://wwwfile.huawei.com/ /media/corp2020/pdf/public-policy/green $5 \mathrm{~g}$ building a sustainable world v1.pdf?la=en 